Swarthmore College

Works

\title{
Imperial Sensibilities, Colonial Ambivalence: Edmund Burke And Frances Burney
}

\author{
Betsy Bolton \\ Swarthmore College, bbolton1@swarthmore.edu
}

Follow this and additional works at: https://works.swarthmore.edu/fac-english-lit

Part of the English Language and Literature Commons

Let us know how access to these works benefits you

\section{Recommended Citation}

Betsy Bolton. (2005). "Imperial Sensibilities, Colonial Ambivalence: Edmund Burke And Frances Burney". ELH. Volume 72, Issue 4. 871-899.

https://works.swarthmore.edu/fac-english-lit/4

This work is brought to you for free by Swarthmore College Libraries' Works. It has been accepted for inclusion in English Literature Faculty Works by an authorized administrator of Works. For more information, please contact myworks@swarthmore.edu. 


\title{
IMPERIAL SENSIBILITIES, COLONIAL AMBIVALENCE: EDMUND BURKE AND FRANCES BURNEY
}

\author{
BY BETSY BOLTON
}

Differing markedly in their approach to social and political theater, Frances Burney and Edmund Burke nonetheless shared a hyperbolic approach to what we might call the economy of imagination. In a 1782 letter celebrating Burney's new novel Cecilia, Burke balanced his praise of the novel with a mild complaint of narrative excess: "Justly as your characters are drawn, perhaps they are too numerous. But I beg pardon; I fear it is quite in vain to preach economy to those who are come young to excessive and sudden opulence."1 Burney returned both the compliment and the complaint in her informal review of Burke's performance at the Warren Hastings impeachment. In one of Burney's many conversations with William Windham, Burke's two admirers discussed his public performance: "How finely,' [Burney] cried, 'he has spoken! with what fulness of intelligence, and what fervour!"” Windham "agreed, with delighted concurrence." "'Yet,—so much!—so long!' I added. 'True!' cried he, ingenuously, yet concerned. 'What pity he can never stop!'”2

Aesthetic economies connect with commercial economies in the political theater of sensibility: as Burke's management of the Hastings impeachment attempted to put an end to the corrupt commercial relations of the East India Company, his legal theatrics worked to stage the political demands of disinterested benevolence, the importance of acting not according to economic self-interest, but according to universal moral claims. Yet Burney's Cecilia had already confronted the sentimental demands of universally benevolent actionand demonstrated the impossibility of meeting those demands: "A strong sense of DUTY, a fervent desire to ACT RIGHT, were the ruling characteristics of her mind: her affluence she therefore considered as a debt contracted with the poor: and her independence, as a tie upon her liberality to pay it with interest." ${ }^{\text {A }}$ As Catherine Gallagher has noted in her reading of the novel, "Disinterested benevolence actually exacts a usoriously high level of interest." After all, Cecilia, 
the heiress, ends up mad in a pawn-shop, marketed in public newspapers. ${ }^{4}$ While she eventually recovers sanity, respectability, and some of her lost wealth, Cecilia's sacrifices remain far greater than her rewards. Critics disliked this sentimental economic imbalance: the English Review, for instance, remarked that "had a flaw in the Dean's will enabled Miss Beverley to enter again into possession of her estate, perhaps the conclusion would have left a more pleasing impression on the mind."5 Burke, meeting Burney socially, remarked that he "wished the conclusion either more happy or more miserable; 'for in a work of imagination,' said he, 'there is no medium."' Though at the time she "was not easy enough to answer him," Burney had much to say "in defence of following life and nature as much in the conclusion as in the progress of a tale; and when is life and nature completely happy or miserable?" $(D, 2: 473)$. In a letter to Samuel Crisp, Burney had already defended her choice: "I must frankly confess I shall think I have rather written a farce than a serious history, if the whole is to end, like the hack Italian operas, with a jolly chorus that makes all parties good and all parties happy!" ( $D, 1: 425)$.

The aesthetic differences between Burney and Burke, articulated by Burney partly in relation to theater, played themselves out politically on the borders of the Hastings impeachment. Preeminent statesman of the Romantic period, Burke was also one of the most flamboyantly theatrical members of parliament-and perhaps the best informed on English India. Appealing to the public through an imagined national sensibility, Burke presented East Indian corruption alternately through the hyperbole and descriptive overlay of romance and through the economic and moral complexities associated with sentiment. Burke's performance at the impeachment first attempted to invoke national agency through the interplay of suffering and systems; over the course of six years, it subsided into a semiprivate exhibition of outrage and uneasy exculpation. One of the most consistent spectators of the trial, Burney resisted Burke's hyperbole, insisting on civility as a medium between Burke and Hastings as legal opponents. Yet as Burney's Diary repeatedly emphasizes the comedy inherent in the trial and works to make all parties good and all parties happy, this female spectator also transforms Burke's melodrama into a farce or Italian opera. ${ }^{6}$ Burney's Diary rewrites the melodrama of the Hastings trial by erasing its Indian context and substituting an occasionally awkward comedy of manners for the cosmic morality of Burke's thunderous declamation. In place of Burke's attempt to invoke the agency of the nation, Burney emphasizes the heterogene- 
ity of the nation as staged at Westminster Hall, focusing on differences among supporters of the prosecution and those of the defense. Yet while Burney's resistance to Burke's staging of empire allowed an eventual reconciliation between novelist and statesman, her attempts to convert party violence to consensus and moral education succeeded only by bracketing all mention of India, and all acknowledgement of the female spectator's own physical and social suffering, her own marginality. The emotional strains visible in Burke's performance and Burney's counter-drama of the trial register the structural demands made on both parties by the political theater of sensibility.

THE HASTINGS TRIAL

At the Hastings impeachment, one of the earliest show trials of colonial rule, Burke abandoned legal precedent and procedure in order to play to history. Believing there was little chance of actually bringing Hastings to trial, he claimed in 1785 to be solely concerned with "what will acquit and justify myself to those few persons and to those distant times, which may take a concern in these affairs." Burke's great speech at the opening of the trial suggests that one plays to history by playing on the emotions of the audience-in this case, an audience composed not only of the House of Lords, but of the luminaries of London society. Burke's opening speech framed the trial within a sentimental translation from suffering to system, explicitly inviting the nation to convert offense into "lustre," suffering into moral reform:

My Lords, it is not only the interest of a great Empire which is concerned . . . but, my Lords, the credit and honour of the British nation will itself be decided by this decision. . . . We are to decide by the case of this gentleman whether the crimes of individuals are to be turned into public guilt and national ignominy, or whether this nation will convert these offences, which have thrown a transient shade on its glory, into a judgment that will reflect a permanent lustre on the honour, justice and humanity of this Kingdom. ${ }^{8}$

Burke here proposed to translate suffering into power by engaging national sentiments against colonial systems of power. In preparing his speech, Burke had sought instances of colonial abuse which might dramatize oppression and thus capture the popular imagination: he looked for scenes of victimage and violence. After discovering John 
Paterson's three-volume report of atrocities committed against men, women, and children in Rangpur, Burke exclaimed: "Oh what an affair, I am clear that I must dilate upon that; for it has stuff in it, that will if any thing work upon the popular sense." ${ }^{\prime 9}$ On 18 February 1788 , the third day of his great opening speech, Burke told a rapt and appalled audience of British peers and London society how "[v]irgins whose fathers kept them from the sight of the sun" were "dragged into the public Court, that Court which was the natural refuge against all wrong, against all oppression, and all iniquity," where they "were cruelly violated by the basest and wickedest of mankind" ( $W, 6: 420$ 21). He went on to describe, still more sensationally, how married women were tortured, their nipples ripped from their bodies, before they were raped with burning torches.

Immediate responses to this sensational representation of violence remained ambivalent: while most spectators were both impressed and shocked, Burke's accusations still seemed scandalously excessive. Blood on Thunder fording the Red Sea, a James Gillray caricature published near the beginning of the trial, captured the uneasiness first evoked by Burke's charges (figure 1). ${ }^{10}$ Hastings, dressed in oriental splendor is "Blood," riding upon the shoulders of "Thunder," or Edward Thurlow, an opponent of the impeachment and chancellor of the trial. Thurlow wades through a sea of blood, past mutilated corpses, dismembered heads tied together by their hair, and other images of torture and atrocity. As a whole, the caricature sides, somewhat uncomfortably, with Burke: his charges may have seemed excessive, but the mutilated nipples of the woman in the foreground stand as a visual-and unanswerable - indictment of Hastings. On the other hand, the World, normally critical of Burke, admired his opening speech but described it as "more vivid-more harrowingand more horrific - than human utterance on either fact or fancy, perhaps, ever formed before." ${ }^{11}$ Either fact or fancy: the enthusiastic reception of Burke's performance was matched by a noncommittal response to the charges themselves; the distinction between fact and fiction seemed almost irrelevant to the moral spectacle presented.

Burke's opening speech lasted for four days, roughly a full day of which was devoted to the material contained in Paterson's report. ${ }^{12}$ The orator's description of the Rangpur atrocities took so long to tell in part because he tried to direct the responses of his audience in remarkably detailed ways. When he comes to display the mutilation of women's bodies, for instance, Burke's syntax becomes circuitous, distracted, disjointed: "In order that nature might be violated in all 


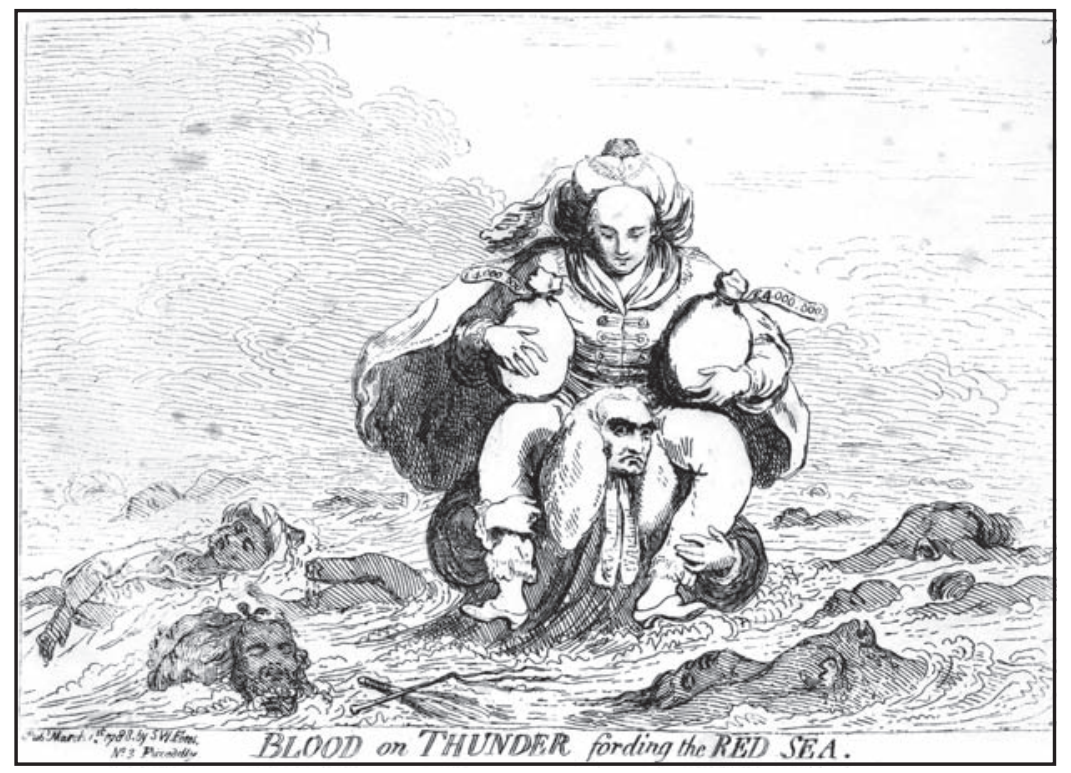

Figure 1. James Gillray, Blood on Thunder fording the Red Sea (1788). This item reproduced by permission of The British Museum (BM Sat 7278).

those circumstances where the sympathies of nature are awakened, where the remembrances of our infancy and all our tender remembrances are combined, they put the nipples of the women into the sharp edges of split bamboos and tore them from their bodies" ( $W$, 6:421). Burke's list of Rangpurian tortures consistently translates specific modes of violence into universal crimes against nature, but this sentence marks the breakdown of that method. Its two halves remain incommensurate-the violence excruciatingly concrete and vivid, the introductory claim an odd mixture of indirection (nature violated "where the sympathies of nature are awakened"), generalization (the double appeal to nature), and possessiveness ("our infancy," "our tender remembrances"). In this sentence, Burke's rhetoric tears the violence from its context, presenting these mutilated breasts as bound up in the tender remembrance of "our" infancy. Even as he seems to take for granted the equality of British and Rangpurian mothers, in other words, Burke's argument assumes the British colonization of the female body as a matter of "nature." The trial of Hastings merely raised the question of how the resources of this female body were to be husbanded by the sons of England: Burke's 
rhetoric reenacts, even as it deprecates, the colonization of Indian women. At the same time, this sentence reveals the prosecutor's participation in the atrocity he recounts: these tortures were not committed in order that "our tender remembrances" be outraged, but they are recounted with that specific effect in mind.

Burke ostensibly invokes these atrocities in order to work upon the public sense, thus bringing the nation to reform the systematic colonial corruption they exemplify. In opening the impeachment, the statesman sketched the English system of government as a counterweight to the corruption of the company: "[I]t was time for the justice of the Nation to exert itself. To have forborne any longer would not have been patience, but collusion - a participation in guilt and almost party with the Criminal" ( $W, 6: 273$ ). Collusion and participation in guilt could be avoided only through active resistance to the commercial and political systems of colonialism. Yet Burke repeatedly emphasizes the impossibility of evading these contagious systems: indeed, he charges Indian victims of colonial abuse with "participation in guilt," reframing their "patience" in suffering as "Criminal" passivity. Indeed, by the time Burke called upon the agency of the nation to convict Hastings, that national agency had already failed to perform in properly moral ways. Back in 1783, defending Charles James Fox's East India Bill, Burke had already urged the nation to take action on East Indian affairs. While his speech urges East Indian reform with great eloquence, however, it speaks still more powerfully of reform as a cause already lost. From the opening of the speech, Burke presents parliamentary ambivalence on the question of Indian affairs as an opponent at least as powerful as the evils of the East India Company:

It is now to be determined whether the three years of laborious parliamentary research, whether the twenty years of patient Indian suffering, are to produce a substantial reform in our Eastern administration; or whether our knowledge of the grievances has abated our zeal for the correction of them, and whether our very enquiry into the evil was only a pretext to elude the remedy which is demanded from us by humanity, by justice, and by every principle of true policy. $(W, 5: 381)$

Chivalry (humanity, justice, true policy) can be demonstrated only through action: specifically, the act of reform, the revocation of the company's charter. Any other response becomes in this context a form of duplicity, evasion or cowardice. Yet Burke's eloquence is perhaps nowhere more finely tuned than in articulating the inner obstacles to 
this act of English chivalry and reform which he demands. Stating plainly that "[o]ur Indian government is in its best state a grievance," he also articulates the difficulties of his own position and that of his audience: "But it is an arduous thing to plead against abuses of a power which originates from your own country, and affects those whom we are used to consider as strangers." Public and private selfinterest alike militate against redressing the grievances which constitute England's Indian government:

[T] he destroyers of the nobility and gentry of a whole kingdom . . . marry into your families; they enter into your senate; they ease your estates by loans; they raise their value by demand; they cherish and protect your relations which lie heavy on your patronage; and there is scarcely an house in the kingdom that does not feel some concern and interest that makes all reform of our eastern government appear officious and disgusting; and, on the whole, a most discouraging attempt. In such an attempt you hurt those who are able to return kindness or to resent injury. If you succeed, you save those who cannot so much as give you thanks. All these things shew the difficulty of the work we have on hand: but they shew its necessity too. $(W, 5: 403-4)$

The most insidious evil of colonialism remained its pervasive corruption, the spread of ill-gotten gains and local power throughout the kingdom of Britain as well as that of India. Yet complicity and collusion became, almost paradoxically, Burke's chivalric challenge to the House of Commons: "[I]f we are the very cause of the evil, we are in a special manner engaged to the redress" (W, 5:385-86). Despite Burke's romance vision of redress, however, chivalry fell on the field of battle. The House voted against the bill, and its defeat rapidly brought down the North-Fox ministry (which Burke supported).

The spectacle of the Hastings impeachment reflected both this prior failure of national agency and Burke's hyperbolic attempts to overcome this defeat. To bring national agency to bear against sociopolitical systems, one must separate (at least conceptually) both nation and agency from the system under attack. Burke attempted to produce this impossible separation by embodying the system of colonialism within a single individual (Hastings). Where this strategy failed-the systems of colonialism repeatedly exceeding corporeal bounds-Burke attempted to abject colonial corruption by displacing the overflow of corruption onto Indian administrators. Finally, Burke’s attack on Hastings and his functionaries broke down into a perfor- 
mance of moral disease, as the statesman was taken ill during the middle of his opening speeches. These three strategies-embodiment, abjection, and disease-replay the colonial confusion of national boundaries as a disruption of physical and moral boundaries, and emphasize the connections between Burke's performance and his notion of national identity.

Burke's attack on Hastings was most emphatically an attack on the entire system of colonial rule-but the shift from reform bill to criminal impeachment required Burke and his fellow managers to establish Hastings's sole responsibility for the crimes of colonialism. Burke's rhetoric repeatedly registers the strain of depicting such singular systematicity:

My Lords, if Mr Hastings had contended, as all the rest of the men in the world contend, that the system of Government which he patronizes, and on which he pretended to act, was a good system, tending on the whole to the blessing and benefit of mankind, possibly something might be said for him for setting up so wild, absurd, irrational and wicked a system. Something might be said from the intention to qualify the act. But it is singular in this man, that . . . that very system upon which he first governed, and under which he now justifies his Actions, did appear to himself a system pregnant with a thousand evils and a thousand mischiefs. The next thing that is remarkable and singular in the principles upon which the Governor General acted is that when he is engaged in a vicious system, which clearly leads to Evil Consequences, he thinks himself bound to realize all the Evil Consequences involved in that system. All other men have taken a directly contrary course. They have said: I have been engaged in an Evil system, that led indeed to abusive Consequences; but I have taken care by my own virtues to prevent the evils of the system under which I acted. Mr Hastings foresees the abusive and corrupt consequences, and then he justifies his conduct upon the rapacities of that System. These are things which are new in the world. (W, 6:375)

Burke's hyperbolic redundancy here multiplies Hastings's singularities into their own self-replicating system; the capitalizing of "Evil Consequences" suggests the simplistic and toothless extremes to which he was driven. This entire passage reduces to two simple points: 1) Hastings acted under a system he recognized as vicious; and 2) he worked to "realize" its evil consequences. Burke's hyperbole develops from the necessity of holding Hastings solely accountable for the colonial system: first, Burke sets Hastings against "all the 
rest of the men in the world;" then, in order to substantiate this unlikely division, Burke emphasizes the evils of the system, showing that all other men would have drawn back from such moral extremity. By 1788, however, colonial abuses were only too familiar to English audiences: after all, conqueror and colonizer Robert Clive had been tried for corrupt governance of India back in 1773. Burke's hyperbole, linking systematic corruption to personal singularity, unravels its own claims.

Failing to contain the evils of colonialism within Hastings himself, Burke sought other ways of disentangling national agency from this system of exploitation. While Burke's management of the trial consistently held Hastings responsible for all of his subordinates and their actions, by shifting the focus from Hastings to his administration, Burke increased both the range of his indictment and (ostensibly) the distance between colonial corruption and English justice. Yet charges such as the Rangpurian atrocities fell into the grey area thus produced between English and Indian systems. Paterson's unsubstantiated report, the source of Burke's opening speech, was based on accounts of people who feared retribution for an armed uprising, and the atrocities it described could not be attributed directly to Hastings but only to his Indian subordinates. In other words, even in the midst of an ongoing attack on the East India Company and its English governor, Burke fell into the colonial stereotype by which white men (the House of Lords) were asked to save dark-skinned women from the violence of dark-skinned men. The outrageous spectacle of female suffering ultimately justified the foreign rule it was produced to condemn. ${ }^{13}$

As Burke worked to abject colonial corruption from English government, he repeatedly denounced the forms of government mediating between England and India. Indeed, what seems to have horrified Burke most about the East India Company's system of government was the racial and administrative intermixing it produced: the half-measures of England's Indian government could be seen as undermining British (self-)mastery both at home and abroad. In describing the figure of the "Black Banyan," for instance, Burke asserts that while Englishmen believed themselves to be ruling over Indian subjects, the opposite was closer to reality:

The moment a Company's Servant comes there . . . that class of people ... take possession of him, as if it [he] were their inheritance ... and it is much to be lamented that they do continue a tyranny not 
only over the people but over the Master, who does nothing but give them the ticket of his name. . . This Banyan thus empowered has not only the people under his subjection, but his Master. . . . The Master is no longer a Master; he is the tool in the hands of this man. Actions the most abhorrent to his nature he must see done before his face and thousands and thousands worse are done in his absence, and he dare not complain of them. The Banyan extorts, robs, murders and gives him what proportion of it he pleases. ( $W, 6: 292-93)$

The confusion between servant and master in this passage operates both nominally ("a Company’s Servant" is a master until "The Master is no longer a Master") and structurally: Indian servitude both produces and transforms itself into mastery. From this perspective, England's claim to administer an empire in India appears farcical at best-the English mere figureheads, and imperial "mastery" but another double-edged tool of Indian despotism.

The colonial paranoia at work in this passage is matched at other moments by an unapologetic racism. ${ }^{14}$ Yet the figure which most consistently oversaw Burke's colonial horror was not that of the banyan, but that of the half-breed colonial system. The banyan merely represented a "class of people" produced by the system of colonial power:

Having been themselves subject to oppression, they are fitted perfectly (for that is the true education); they are fit to oppress others. They serve an apprenticeship of servitude to qualify them for the trade of tyranny. They are pawns without whom an European can do nothing. They know, they themselves being trained in that way, they know all the ways, all the little frauds, all the defensive armour, all the artifices and contrivances, by which abject slavery secures itself against the violence of power. ( $W, 6: 292-93$ )

Spokesmen for the East India Company had traditionally insisted they were merely merchants, carrying out a legitimate trade and, when necessary, taking military action to protect that trade. In considering the ways and means of the Indian administration, Burke redefines that trade as tyranny, and charges the system with producing a "class" of people expert in turning the "violence of power" against both their own country-people and against their ersatz masters.

Within this nightmare vision of a system ceaselessly reproducing violence and abject slavery, any participation is culpable. Yet the episodic and expansive nature of Burke's attack on Hastings and the 
East India Company meant that his audience was necessarily selective in its reception of the attack; listeners might choose, for example, to blame not the despotism of the company but the immorality of its Indian functionaries for the evils Burke described. Indeed, Burke's discussions of "Geographical morality" show how easily his insistence on universal morality could be turned against India. Burke claimed that Hastings and his associates

\begin{abstract}
formed a plan of Geographical morality, by which the duties of men in public and private situations are not to be governed by their relations to the Great Governor of the Universe, or by their relations to men, but by climates, degrees of longitude and latitude, parallels not of life but of latitudes. This Geographical morality we do protest against. ... The laws of morality are the same everywhere, and ... there is no action that would pass for an action of extortion, of peculation, of bribery and of oppression in England, that is not an act of extortion, of peculation, of bribery and of oppression in Europe, Asia, Africa, and all the world over. (W, 6:346)
\end{abstract}

This speech was taken as a great advance in the prosecution's casea blow struck for liberal morality. Yet some traditional systems of Indian government had involved a finely tuned system of bribes and presents: Hastings's crime lay in profiting from these systems of local governance. It takes fifteen pages before Burke belatedly clarifies India's equal claim to moral virtue: "I assert that their morality is equal to ours as regards the morality of Governors, fathers, superiors; and I challenge the world to shew, in any modern European book, more true morality and wisdom than is to be found in the writings of Asiatic men in high trusts and who have been Counsellors to Princes. This is to be set against that geographical morality to which I have referred" ( $W, 6: 361)$. In the intervening passages, however, listeners could easily have lost the thread of the argument — or made their own decisions about the relative value of English and Indian morals.

Burke's performance offers one last option for unraveling the systematic interweaving of English and Indian peoples and customs. In response to what he saw as the systematic corruptions of Britain's Indian empire, Burke attempted to model an act of self-division by which Britain's role in colonial atrocities might be transformed into passive participation in suffering (sympathy) and an active dismantling of the system (benevolence). Burke introduced his account of the Rangpur atrocities with an apology for the "scenes" he was about to "unfold" and "display" (W, 6:418). This prefatory apology, based on 
that of Paterson, serves both as a marker of moral contagion and as an apotropaic gesture, an averting of such contagion:

[T]he punishments inflicted upon the Ryots, of both Rungpore and Dinagepore for non-payment, were in many instances of such a nature, that I would rather wish to draw a veil over them than shock your feelings by the detail. But, however disagreeable the task may be to myself, it is absolutely necessary for the sake of justice, humanity, and the honour of Government, that they should be exposed, to be prevented in future. $(W, 6: 418)$

This "apology" asserts a complicated model of moral complicity. In describing the punishment inflicted on the people of Rangpur, Burke and Paterson present themselves as inflicting a similar punishment on their civilized, sentimental audience-and on themselves ( $W$, 6:418). Reporting or restaging atrocities enacts a (mediated) atrocity in shocking the feelings of the audience. Yet the apology shared by Burke and Paterson splits the punishment, the disagreeable shock of exposure, between audience and reporter: the reporter of atrocities thus simultaneously inflicts and suffers pain. A performance of his own suffering attests his moral distance from the atrocities he replicates, ostensibly in order to prevent their recurrence. Burke's illness, his inability to continue speaking this third day of the trial, constitutes just such a sentimental performance.

Burke structured the impeachment around the presumed existence of a sentimental or chivalric accord among English gentlemen: a community of natural feeling, which the reporting of atrocities might channel into political redress, producing justice for India. The demonstrable absence of this (assumed) universal benevolence marked the extended breaking point of the prosecution-and of Burke's opening performance. Burke was taken ill not during the actual description of atrocities but shortly afterwards, as he reflected on the disbelief with which Paterson's report had been received by the company:

[T] hey suppose that a man of such diligence, who made up three such volumes as these, is carried away with the warmth of imagination, though he can be proved to be the coldest and most phlegmatic of men, though at the same time they allow there is presumptive proof pretty strong against Debi Sing, and though Mr Hastings is of the opinion that there is nothing here charged against him of which he is not capable.

Here Mr Burke was taken ill and obliged to sit down. (W, 6:426) 
Paterson here operates as a figure for Burke himself, and for the disbelief Burke feared his restaging of atrocities might evoke. At the same time, the possibility of disbelief (re)engages the larger issue of colonial responsibility and authority, raising the question, "Who were the authors of their [Rangpurian] oppression?" (W, 6:419). Hastings, by proxy? Debi Singh? The rebellious people of Rangpur, playing on an Englishman's credulity? Paterson? Burke himself? One might well argue that the atrocities as reported at the impeachment were produced through an uncanny and unholy collaboration among all these parties. Burke's illness works to remove him from this chain of collusion. He presents his (performance of) illness as a symbol of his suffering, and of his chivalry: "My Lords, I am sorry to break the attention of your Lordships in such a way. It is a subject that agitates me. It is long, difficult, and arduous; but with the blessing of God, if I can, to save you any further trouble, I will go through it this day" ( $W$, 6:426). Burke's "arduous" labors mark the outer bounds of colonial complicity, and of its counterpart: imperial sensibility.

Burke's predominantly theatrical handling of the India question demonstrates both the contagion of colonial ambivalence and the inadequacy of romance and sensibility as political responses to the economic conflicts of colonialism. Burke chose to stage the corruption of Anglo-Indian relations in an appeal to the power of public opinion: the political theater he invoked left him dependent on the response of his audience. But Burke's speech in support of Fox's East India Bill had already dramatized the limits of sentiment as a political intervention: his rhetorical success in unmasking his opponent-the systemic evils of the East India Company-had resulted only in the resounding political defeat of the North-Fox coalition government. Burke's performance in the consolation prize of the Hastings impeachment oscillated between romantic hyperbole and a sentimental articulation of self-division and systemic complicity. Over the six years of the Hastings trial, however, sentimental politics turned to farce as Burke's performance of moral indignation at Hastings's impeachment was increasingly read as a self-consuming artifact. By 8 May 1795, two weeks after Hastings's acquittal, James Sayers could summarize the trial's conclusion as The last Scene of the Managers Farce (figure 2), dismissing Burke's attack on Hastings and the East 


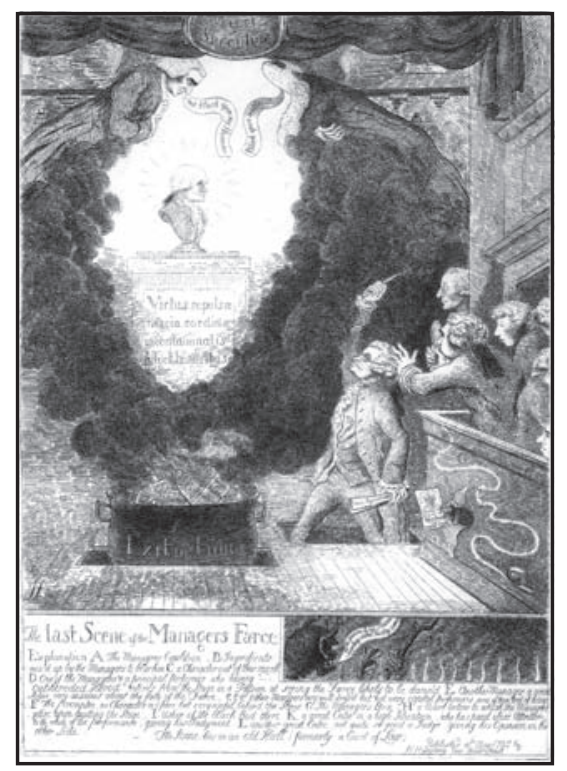

Figure 2. James Sayer, The last Scene of the Managers' Farce (1795). This item reproduced by permission of The British Museum (BM Sat 8647).

India Company as empty theatricals, and turning the orator's fire and brimstone back on his own head. ${ }^{15}$

Ironically, however, while this elder statesman failed in his ostensible attempt to develop British sympathy for the particularities and details of a distant people's suffering, he succeeded in winning admiration for his own sentimental performance of moral feeling and his vision of a government structured along universal principles of justice-a vision which was later used to rule India according to British rather than Indian laws and customs. At the trial, Burke opened his indictment of Hastings with the claim, "The Commons will not have the melancholy and unsocial glory of having acted a right part in an imperfect work. What the greatest Inquest of the Nation has begun, its highest Tribunal will accomplish. Justice will be done to India" ( $W, 6: 270)$. Liberal reformers such as Jeremy Bentham and John Stuart Mill, resisting Burke's indictment of colonialism, nonetheless inherited one part of his imperial mantle: British justice did indeed become a part of what was done to India. 
In 1782 - one year before Fox's East India Bill was presented to Parliament and four years before the start of the Hastings trial-a comedy entitled The East Indian was presented anonymously at the Haymarket Theatre under the management of George Colman. In his biography of Sarah Siddons, James Boaden attributes the play to Frances Burney, as if there were no doubt of her authorship. In the process he notes that the play's flaws bear a remarkable resemblance to Burney's novelistic strengths:

\begin{abstract}
What is extraneous is of the novel cast also-Savage, a character of morbid sensibility, always ready at the call of benevolence; a poor but proud family, such as her novels had exhibited, and a common plague, in one of those importunate beings, who force their advice upon every living thing that comes within their sphere of action. The effect of all this was but weak, though the language of the piece was delightful. ${ }^{16}$
\end{abstract}

The comedy seems worth mentioning if only because Burney's journal of the Hastings trial shares with The East Indian a tendency to exclude the East Indies from consideration, focusing instead on the English actors of the drama. The play, despite its title and prologue, is set entirely in England, and the East Indies operate only as a series of obstacles to true love: colonialism explains the distance separating young lovers, the suitor's rash impetuosity (an apparent result of his Anglo-Indian blood), the heroine's (rumored) loss of her lover to the fortune of an Indian princess. Burney's response to the Hastings trial likewise elided its ostensible occasion and cause: England's Indian empire. Burney read the trial as a misguided contest between two Englishmen, both of whom she admired, and as a manifestation of party politics, which she affected to despise. ${ }^{17}$ Finally, as if recapitulating the sentimental comedy rehearsed by The East Indian, Burney framed Burke's tormented demonstration of the political failure of romance and sensibility within a more satisfying series of encounters between herself and "a young man of fashion": Burke's supporter and fellow manager, Mr. Windham (D, 3:420). Burney's reception of the trial thus allowed for a highly mediated, still-sentimental resolution to the conflict staged between Burke and Hastings: it did so by bracketing almost all mention of India and Indians. 
Burke's flamboyant management of the Hastings trial sketched the disease of national agency, the impossibility of bringing "the justice of the Nation" to bear upon systems from which "the Nation" profited. By contrast, Burney's responses to the trial suggested the complexities involved in constructing agency within the nation ( $W, 6: 273$ ); yet her reception of the trial also recorded the constraints produced by the sentimental community Burke failed to move. Burney, the most consistent female spectator of the Hastings impeachment, considered herself, like Burke, a performative spectator of injustice. Specifically, Burney's Diary constructed a revisionary drama of the trial, staged in the gallery of Westminster Hall through conversations between her and Burke's junior colleague Windham. Where Burke's reform efforts suffered from the failure of a sentimental accord, Burney insisted on the social coherence and support of the systems within which she found herself. Burney's assertions of public morality emphasized personal connections (her own social knowledge of Hastings, the views of the king and queen), yet insisted on the impersonality of her responses to the trial. As Burke's melodramatic staging worked to separate English sheep from colonial goats, Burney's courtly reception of the trial worked to overcome party violence by reinstating civil codes of conduct as a basis for discussion and possible reconciliation. Nonetheless, while Burney's framing of the trial positioned her within a system of royal allegiances, her scrupulously unarticulated misery in court life consistently troubled the systems she promoted.

Burney's account of attending the trial in the midst of her duties as courtier to Queen Charlotte took shape as a mixed genre of narrative and dialogue, something between a novel and a play. From the beginning, Burney carefully framed her own appearance at the trial: she attended through the queen's generosity and at her pleasure. ${ }^{18} \mathrm{In}$ return, Burney served as a kind of court reporter, repeating and often performing the high points of each day's events: "On my return I was called upon to give an account of the trial to their majesties and the princesses. 'Tis a formidable business, I assure you, to perform" ( $D$, 3:259). In her performances, Burney emphasized the importance of intonation and effect: "The words may be given to the eye, but the impression they make can only be conveyed by the ear; and I came back so eagerly interested, that my memory was not more stored with the very words than my voice with the intonations of all that had passed" $(D, 3: 329)$. One reward for a pleasing performance seems to have been continued attendance at the trial. When Burney empha- 
sized one day that "[i]t gave me great pleasure to repeat so striking an affirmation of the innocence of so high, so injured I believe, a character" the pleasure was not hers alone: "The queen eagerly declared I should go again to the next sitting" ( $D, 3: 261)$. Burney's court connections made it possible for her to be one of the most regular female spectators of the trial, as well as the most articulate. In 1792 she remarked, "I am now so known in the chamberlain's box that the door-keepers and attendants make way for me without looking at my ticket. And to be sure, the managers on one side, and Mr. Hastings's friends and counsel on the other, must pretty well have my face by heart. I have the faces of all them, most certainly in full mental possession" ( $D, 3: 401)$.

Spectatorship, however, complicated both mental possession and Burney's ideal of self-possession. Much to her chagrin, Burney's personal support for Hastings and her more general role as royal courtier at times seemed belied by her popularity with the Whig prosecution, the managers of the trial. From the start she was sought out by opposition figures such as Windham, Burke, and Richard Sheridan. At once grateful for and embarrassed by Burke's notice, she consistently cold-shouldered him: "However I might be obliged to him, which sincerely I felt, I was yet glad to have him go. My total ill will to all he was about made his conversation merely a pain to me" $(D, 2: 524)$. Sheridan she snubbed (however indiscernibly) with even less compunction: " $[\mathrm{T}]$ he part he acts would take from me all desire for his notice, even were his talents as singular as they are celebrated. Cold, therefore, was my reception of his salutations, though as civil as I could make it" ( $D, 2: 534)$. Yet she remained willing to converse at length with the more junior Windham: "He is not the prosecutor, and seems endowed with so much liberality and candour that it not only encourages me to speak to him what I think, but leads me to believe he will one day or other reflect upon joining a party so violent as a stain to the independence of his character" (D, 2:524). Windham's most important attribute in Burney's eyes appears to have been his disinterested affection for two old men she herself dearly loved: the Tory Samuel Johnson, and the Whig Burke-in part because Windham's demonstrated respect for Johnson's declared party opposition opened the way for Burney's own candid political remarks. ${ }^{19}$

Burney's personal and political authority in her conversations with Windham developed partly as a result of her literary reputation, partly through her understated force of character, and partly from the trial's mingling of court, society, and theater. In this context, theater 
criticism offered an ambivalent arena of civil and political debate. Burney recorded the theatricality of the trial through a range of different voices, most notably, perhaps, that of Jeremiah Crutchley:

"Well, ma'am, what say you to all this? how have you been entertained?" cried a voice at my side; and I saw Mr. Crutchley, who came round to speak to me.

"Entertained?" cried I, "indeed, not at all; it is quite too serious and too horrible for entertainment: you ask after my amusement as if I were at an opera or a comedy."

"A comedy?" repeated he, contemptuously; "no, a farce; 'tis not high enough for a comedy." $(D, 2: 510)^{20}$

Crutchley's view of the trial as vulgar entertainment captures its bizarre mingling of social and legal form. Windham's opening remarks to Burney, for instance, define him quite strikingly as the young man of fashion rather than the young prosecutor: "What an assembly is this! How striking a spectacle! I had not seen half its splendour down there. You have it here to great advantage; you lose some of the lords, but you gain all the ladies. You have a very good place here" $(D, 2: 487)$. In highlighting the social assembly-and valuing the ladies over the lords-Windham frames the scene as one of social theater rather than legal conflict: he plays, in other words, to what he considers a lady's perception of the affair. Burney herself soon rejects this level of conversation, and declares herself his political opponent in terms of the trial and its outcome. Once her position has been made clear, however, she claims to retreat to a slightly different arena of social theater: “'But, Mr. Wyndham,' cried $\mathrm{I}$, 'all my amazement now is at your condescension in speaking to me upon this business at all, when I have confessed to you my total ignorance of the subject, and my original prepossession in favour of the object. Why do you not ask me when I was at the play? and how I liked the last opera?"' $(D, 2: 495)$. In context, of course, this more ladylike conversation remained impossible to distinguish from explicitly political dialogue.

The spectacle of the trial left its social status-and that of its spectators-ambiguous, and Burney manipulated this ambiguity with great care. She remarks somewhat disingenuously to both Windham and her journal readers, "I not only am no politician, but have no ambition to become one, thinking it by no means a female business" $(D, 2: 546)$. Yet while maintaining amateur status as a woman ignorant of explicitly political matters, Burney claims natural authority in 
political affairs through a theatrical analogy. She tells Windham, "Molière, you know, in order to obtain a natural opinion of his plays, applied to an old woman; you, upon the same principle, to obtain a natural opinion of political matters, should apply to an ignorant one;--for you will never, I am sure, gain it down there"' (D, 2:527). Over the next few conversations, Burney returns to the figure of Molière's old woman whenever she wants to call Windham's attention to a political point. She notes, for instance, the injustice of Fox's pausing after each charge to look at Hastings as if the prisoner had the option of responding, thus making his silence either a further humiliation (Burney's point) or a suggestion of his guilt; Windham, however, insists the gesture is merely standard parliamentary practice. Burney also complains about the general stage-managing of the trial:

\begin{abstract}
"And another thing," I cried, "which strikes those ignorant of senatorial license, is this, - that those perpetual repetitions, from all the speakers, of inveighing against the power, the rapacity, the tyranny, the despotism of the gentleman at the bar, being uttered now, when we see him without any power, without even liberty . . . when we see such a contrast to all we hear, we think the simplest relation would be sufficient for all purposes of justice, as all that goes beyond plain narrative, instead of sharpening indignation, only calls to mind the greatness of the fall, and raises involuntary commiseration!" $(D, 2: 530-1)$
\end{abstract}

The descriptive overlay which Burke brought to the trial injured the managers' legal case with more spectators than Burney. It seems worth noting, however, that this descriptive excess is also a dwelling on the injustices done to India and Indian citizens by British colonial administrators: injustices elided by Burney's response to the trial. This female spectator, responding to the staging of the trial, engages the charges against Hastings only through their presentation.

Windham, urging Burney to "come and hear Burke," tried, by contrast, to combine form and content, delivery and discovery-but fell into Burke's own mode of hyperbole: "Come but and hear him! 'tis an eloquence irresistible! — a torrent that sweeps all before it with the force of a whirlwind! It will cure you, indeed, of your prepossession, but it will give you truth and right in its place. What discoveries has he not made! - what gulfs has he not dived into! Come and hear him, and your conflict will end!" $(D, 2: 504)$. With the help of the queen, Burney did go to hear the second day of Burke's great opening 
speech, and her initial response as recorded in her Diary, seemed overwhelmingly favorable: "All I had heard of his eloquence, and all I had conceived of his great abilities, was more than answered by his performance." While acknowledging that the speech was "unequal," she insisted on its "irresistible" effect overall ( $D$, 2:509). While Burney retained her reservations about Burke's motivations and the validity of his evidence, she also confessed, in words that echoed Windham's prophecy, "[W]ith all that I felt, wished, and thought concerning Mr. Hastings, the whirlwind of his [Burke's] eloquence nearly drew me into its vortex" $(D, 2: 509)$. Yet in describing the effects of this speech to Windham, Burney invokes social theater to resist the force of Burke's performance. Burney claims that, to begin with, Burke's narration "interested," "engaged," and

at last overpowered me; I felt my cause lost. I could hardly keep on my seat. My eyes dreaded a single glance towards a man so accused as Mr. Hastings; I wanted to sink on the floor, that they might be saved so painful a sight. I had no hope he could clear himself; not another wish in his favour remained. But when from this narration Mr Burke proceeded to his own comments and declamation ... then there appeared ... so little of proof to so much of passion, that in a very short time I began to lift up my head, my seat was no longer uneasy, my eyes were indifferent which way they looked, or what object caught them; and before I was myself aware of the declension of Mr. Burke's powers over my feelings, I found myself a mere spectator in a public place, and looking all around it, with my operaglass in my hand! ( $D, 2: 528)$

The vulgar excesses of Burke's speech remind Burney of her status as a lady of fashion, attending a society spectacle. And by presenting his speech and her response as a drama in which the crisis is followed by an anticlimactic denouement, Burney suggests that Burke's excess, like the staging of the trial more generally, defeats its own purposes. While Burke's own rhetoric insistently mingles narrative and interpretation-claiming, for instance, that women were tortured in order to outrage the sentiments of his London audience-Burney's replay of his speech scrupulously distinguishes between apparently factual narrative and purely passionate declamation. ${ }^{21}$

Yet if, as Burney claimed, Burke's political enthusiasm overwhelms his factual narrative, theatricality also functions as a kind of formal contagion within Burney's journal of the trial. While the English Review had praised the characters within Cecilia, insisting they had 
been "fairly purchased at the great work-shop of life and not the second-hand, vamped-up shreds and patches of the Monmouthstreet of modern romance," Burney's counter-drama of civil debate, staged on the borders of Burke's colonial melodrama, engages the problem of political heterogeneity only through a medley of theatrical rags and patches. ${ }^{22}$ And if Burney's Diary stages her encounters with Windham as something between a drama of conversion and a courtship by instruction, theatrical echoes in their conversation record both their mutual engagement in this drama of national agency and their mutual refusal to convert, to alter their political positions. ${ }^{23}$ Burney's conversations with Windham take shape as a drama of failed conversion in which echoes of Shakespearean (and thus national) tragedy register the formal rigidity of their political positions.

Early in their conversations Windham, looking at Hastings apparently for the first time in court, responds to the Shakespearean tragedy implicit in his appearance: "What a sight is that! to see that man, that small portion of human clay, that poor feeble machine of earth, enclosed now in that little space, brought to that bar, a prisoner in a spot six foot square-and to reflect on his late power! Nations at his command! Princes prostrate at his feet! What a change! how must he feel it!" Burney declares herself "glad to see him thus impressed; I hoped it might soften his enmity" ( $D, 2: 489)$. Yet Windham moves from apparent sympathy with Hastings's nightmare enclosure at the bar of Westminster Hall to the long shadow of physical suffering cast by his imperial administration:

[S] uddenly rousing himself, as if recollecting his "almost blunted purpose," he passionately exclaimed, "Oh could those- the thousands, the millions, who have groaned and languished under the iron rod of his oppressions - could they but . . see him there . . . it might prove, perhaps, some recompense for their sufferings!” $(D, 2: 489)^{24}$

Where Windham's rhetoric cast Hastings as Hamlet haunted by bad dreams, Burney's explicit quotation (his "almost blunted purpose") casts Windham himself in the role of the melancholy prince who must be recalled by his father's ghost to the task of killing his uncle. Burney will later suggest to Windham that Hastings actually looks like his uncle, while Burke was clearly a father figure for the young politician. Burney chooses for herself, meanwhile, the role of a rebellious daughter at the start of a yet more apocalyptic vision of 
social upheaval. Professing herself shocked at Windham's words, Burney nonetheless says nothing, insisting to her journal, "I could only be sorry, and silent." So Lear's Cordelia, confronted with an impossible demand for social performance, remarks in a famous aside, "What shall Cordelia speak? Love, and be silent."25

Another reference to Hamlet registers Burney's greatest point of influence over her opponent. When Windham acknowledges Hastings's sensibility ("Hastings has feeling-'tis a proud feeling, an ambitious feeling-but feeling he has! . . . The moment of his punishment-I think it, upon my honour! — was the moment that brought him to that bar!"), Burney is quick to reward her companion by expressing how "affecting" she finds this "liberality from a foe" (D, 2:506). She notes that Windham too was affected by their conversation, to the extent that when he rose to leave "he said with great quickness, 'I must shake all this off; I must have done with it_-dismiss it—forget that he is there." Burney immediately protests:

"No, remember it rather," cried I; "I could almost (putting up my hands as if praying) do thus; and then, like poor Mr. Hastings just now to the house, drop down on my knees to you, to call out "Remember it."”

"Yes, yes," cried he, precipitately, "how else shall I go on? I must forget that he is there, and that you are here." And then he hurried down to his committee. (D, 2:506-7)

In pressing home her point, Burney herself takes on the role of Hamlet's ghost, exerting influence through a virtual image and a pithy command-but her goal, as Windham pointed out, is to blunt her companion's purpose. Burney closes her account of this exchange with the remark, "Was it not a most singular scene?" $(D, 3: 507)$. Yet when she describes it to the queen (moving her mistress to tears by the account), the courtier downplays the singularity and conscious theatricality of her own performance, focusing instead on Windham's "liberality" and openness to influence.

Reenacting scraps of Shakespearean tragedy, Burney and Windham communicated as if in quotation marks, reiterating positions rather than negotiating them. Perhaps for this reason, gallantry—an equally formulaic mode of communication-presented these characters' best hope for political reconciliation. Indeed, male gallantry toward women-in particular, toward Frances Burney-gradually became the banner under which a reunion of opposing parties could be 
imagined. One day after Windham had offered to see Burney out of the hall, she came face-to-face with none other than Hastings himself, who gallantly remarked that he must come to court to have the pleasure of meeting with her. On her next encounter with Windham, Burney frames this near meeting of political opponents as a possible rapprochement: "Now, had you but been with me at that moment! I own it would have been the greatest pleasure to me to have brought you together; though I am quite at a loss to know whether I ought, in that case, to have presented you to each other." The young man of fashion responds to this sally with one of his own: "He laughed most heartily,- half, probably, with joy at his escape; but he had all his wits about him in his answer. 'If you,' he cried, 'had been between us, we might, for once, have coalesced-in both bowing to the same shrine!"” $(D, 3: 265)$. If the rape of India embodied in the rape of women constitutes the centerpiece of Burke's show trial of colonialism, Burney recenters the trial around the inviolate figure of the female spectator. Prosecutor and defendant-and the drama of opposition implied in those terms-would vanish into coalescence, in this gallant submission to femininity.

Of course, that inviolate female spectator appears at other moments in Burney's Diary as a victim of social systems defined by their perversely reflexive physical violence. While Burney's health visibly declines over her years at court-as Windham comments frequently and anxiously in their conversations at the trial-the most vivid dramatization of this female spectator's own suffering remains Burney's famous satire on court etiquette, written to her sister Esther in December 1785:

In the first place, you must not cough. If you find a cough tickling in your throat, you must arrest it from making any sound; if you find yourself choking with the forbearance, you must choke-but not cough.

In the second place, you must not sneeze. . . . [I]f a sneeze still insists upon making its way, you must oppose it, by keeping your teeth grinding together; if the violence of the repulse breaks some blood-vessel, you must break the blood-vessel-but not sneeze.

In the third place, you must not, upon any account, stir either hand or foot. . . . If . . . the agony is very great, you may, privately, bite the inside of your cheek, or of your lips, for a little relief; taking care, meanwhile to do it so cautiously as to make no apparent dent outwardly. And, with that precaution, if you even gnaw a piece out, it will not be minded, only be sure either to swallow it, or commit it to 
a corner of the inside of your mouth till they are gone-for you must not spit. $(D, 2: 54-55)$

Burney's account of court etiquette is often viewed as a description of torture-and indeed, the body's violence against itself here sounds remarkably similar to Elaine Scarry's account of how torture makes the victim's own body another tool by which to administer pain. ${ }^{26} \mathrm{I}$ wish only to note that, especially as a site for coalescence and gallant national unity, this suffering female body is not unlike a dim, uneasy echo of Burke's descriptions of Rangpurian women. Burney's refusal to acknowledge publicly the costs of court or colonial rule intensifies the constraints within which she labors to reconstruct political harmony.

Since explicit recognition of her physical and social vulnerability remained unacceptable to Burney, the novelist was unwilling or unable to accept male gallantry that exceeded the bounds of purely verbal form. Hearing of Burney's fatigue, ill health, and lack of time at court, Windham laments her situation, both to her and to her sister Charlotte. Encouraged by the latter, he went further, urging Dr. Burney to bring his daughter home, and setting the Literary Club on to pester her father with the same intent. Burney privately recorded her gratitude for such care ("What a noble Quixote! How much I feel obliged to him! How happy, when I may thank him!" [D, 3:298]). Yet she never publicly expressed more than a formulaic appreciation, apparently fearing her explicit relief would fuel the party gossip she remained anxious to avoid. Thus, despite her delight in returning to private life, Burney thanked Windham for her release only by increasing her attack on the trial. Windham finally remarked, albeit in a "very flattering" tone, "I do not understand, nor can any way imagine, how you can have been thus perverted!' While Burney insisted aloud, "[I]t is you who are perverted!' she acknowledged to her journal, "I fancy this was not exactly the conversation he expected upon my first enlargement" ( $D, 3: 398)$. Indeed, Windham's material service to Burney became a real barrier to their social relations: Windham vanished from Burney's Diary toward the latter years of the trial.

Burke, meanwhile, more able or willing to remain within the bounds of social formalities, reappears in friendlier circumstances, reconciled to Burney through the formulae of gallantry. In 1792, for instance, at a dinner party including both Burke and Burney, Burke's Reflections on the Revolution in France were discussed over dinner. 
When someone remarks that Burke's new support of monarchy might be taken as support for slavery over freedom, Burke responds:

\footnotetext{
"Come then-here's slavery for ever!"

This was well understood, and echoed round the table with hearty laughter.

"This would do for you completely, Mr. Burke," said Mrs. Crewe, "if it could get into a newspaper! Mr. Burke, they would say, has now spoken out; the truth has come to light unguardedly, and his real defection from the cause of true liberty is acknowledged. I should like to draw up the paragraph!"

"And add," said Mr. Burke, "the toast was addressed to Miss Burney, in order to pay court to the queen!" $(D, 3: 420)$
}

Burke's translation of slavery into courtly love uses the social formula of chivalry in order to disavow the content, the materiality of slavery. Repeating Burke's joke, Burney likewise accepts formal tribute in place of more substantial agreement. Chivalry and civility-both linked to the conventions of sentiment-gloss over the material and political differences between opponents. Linking court life to public sense, Burke and Burney both transform the social contract through rhetorical artifice; at the same time, however, each struggles to translate slavery into sociality, illness into moral strength.

In her spectatorship of the trial, Burney erases many of the features most emphasized by Burke's stage management: in particular, East Indian claims to autonomy and respect, and Burke's urgent attempt to construct a national morality. Burke's staging of the impeachment repeatedly links British morality to its East Indian empire, at times insisting that British morality be performed through imperial administration, at times contrasting British morals to East Indian corruption. Yet Burney's reception of the trial erases all direct mention of Indian affairs and, in the process, brackets all question of national morality and national agency. Her comedy stages the problem of competing political views and actions in remarkably formal terms, presenting her debates with Windham through disjointed echoes of Shakespearean tragedy and offering purely formal gallantry as a preferred model for political reconciliation. At the same time, in revising Burke's melodrama, Burney's sentimental comedy of the trial develops a strictly contextual model of morality. Greatly struck by Burke's denunciation of "geographical morality" at the trial, Burney excuses her coldness to him as a form of "geographical timidity" ( $D$, 2:524), turning her reluctance to converse into an apparent compli- 
ment. Yet Burney's compliment was only too aptly turned. While she seems to have admired the universal rhetoric of Burke's claims, her own code of behavior remained largely dependent upon locale: the emotional distance and disapproval required of her by the setting of Westminster Hall could be dispensed with when she met Burke in a private home, though the ostensible source of disapproval, Burke's persecution of Hastings, had not altered. Burney's refusal to acknowledge that a grasp of Indian affairs might serve as a prerequisite to an accurate reading of English character offers a profound yet subtle example of the ways "geographical morality" at times policed the sentimental borders of national identity.

Burney's last play, A Busy Day; or An Arrival from India (1802), presents an odd coda to the theatrical encounters of Burney and Burke. The play as a whole concerns the fate of two young lovers-an East Indian heiress from humble origins, and an East Indian gentleman functionary called home to marry a local heiress - and mocks the social pretensions of upper- and lower-class families alike. In the very first scene of the play, however, Burney sketches the outline of a virtual drama that might be said to transpire concurrently with her comedy of manners:

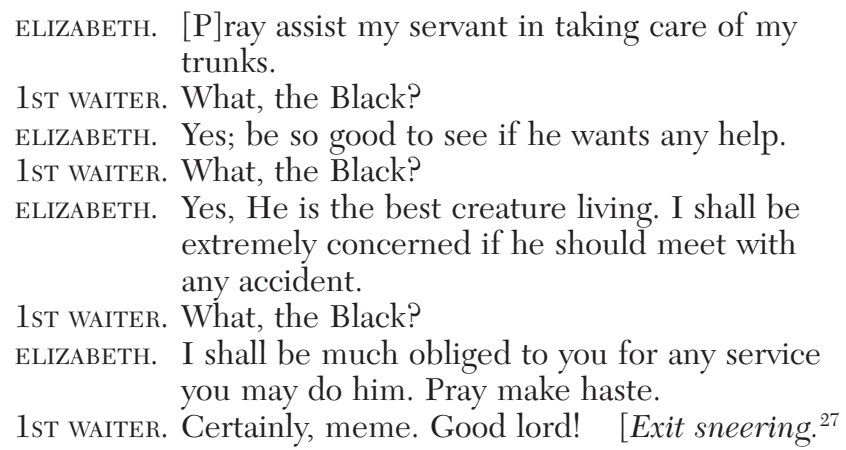

The snide, mechanical repetition of the waiter's disdain captures through comedy the automatic exclusion of nonwhites from service or even recognition. After a similar though briefer exchange with a second servant, the heroine Eliza remarks, "Poor Mungo! my care of you shall be trebled for the little kindness you seem to meet with here." Her housekeeper-companion Deborah, however, responds 
more bracingly: "[T] hese Gentlemen mean no harm, I dare say; for after all, a Black's but a Black; and let him hurt himself never so much, it won't shew. It in't like hurting us whites, with our fine skins, all over alabaster." In acceding to the spectacular assumptions of sentimental drama, Deborah casts herself as injured heroine ("I dare say if you was only to look at my arm up here") and insists that violence be visible in order to claim our sympathies. ${ }^{28}$ At the same time, the play itself insists on making not only Mungo's injuries, but even his person, invisible. Eliza's care is not "trebled," nor is it even mentioned again: Mungo remains a virtual character, never seen on stage. Both the spectacular sufferings of East Indians under British rule and the "little kindness" they meet in London remain just out of sight. Yet by beginning her Arrival from India with this virtual abuse of "the Black," Burney here directs her spectators' attention to the margins of England's imperial drama-and draws attention to the absences enabling her own sentimental resolution of social disparity.

\section{Swarthmore College}

\section{NOTES}

${ }^{1}$ Edmund Burke, Letters, 29 July 1782, reproduced in Frances Burney, Cecilia; or, the Memoirs of an Heiress, 2 vols. (London: George Bell and Sons, 1904), 1:xxii.

${ }^{2}$ Burney, Diary and Letters of Madame D'Arblay, ed. Charlotte Barrett, 4 vols. (London: Swan Sonnenschein \& Co. 1892), 3:263. Hereafter abbreviated $D$ and cited parenthetically by volume and page number.

${ }^{3}$ Burney, Cecilia, 1:52.

${ }^{4}$ Catherine Gallagher, Nobody's Story: The Vanishing Acts of Women Writers in the Marketplace, 1670-1820 (Berkeley: Univ. of California Press, 1994), 237.

${ }^{5}$ English Review 1 (January 1783): 15-16.

${ }^{6}$ On the first day of her attendance, for instance, a prior acquaintance offered to orient Burney to the physical and human paraphernalia of the trial: "she knew, she said, 'all those creatures that filled the green benches, looking so little like gentlemen, and so much like hair-dressers.' These were the Commons" (2:411).

${ }^{7}$ Burke, The Correspondence of Edmund Burke, ed. P. J. Marshall, 10 vols. (Cambridge: Cambridge Univ. Press, 1965), 5:241-42.

${ }^{8}$ Burke, The Writings and Speeches of Edmund Burke, ed. Marshall, 9 vols. (Oxford: Clarendon Press, 1991), 6:271. Hereafter abbreviated $W$ and cited parenthetically by volume and page number.

${ }^{9}$ Burke, quoted in Marshall, The Impeachment of Warren Hastings (Oxford: Oxford Univ. Press, 1965), 84.

${ }^{10}$ The caricature was published by Humphreys on 1 March 1788.

${ }^{11}$ The World's review of Burke's speech is quoted by Marshall in Burke, Writings, $6: 460$.

${ }^{12}$ Burke spoke for roughly three hours each of the first three days, and two hours the final day of the speech. The Rangpur atrocities occupied a substantial portion of both the third and fourth days. 
${ }^{13}$ See Sara Suleri's discussion of the trial in her The Rhetoric of English India (Chicago: Univ. of Chicago Press, 1992).

${ }^{14}$ Burke claimed, for instance, "White men are loose and licentious; they are apt to have resentments, and to be bold in revenging them. Black men are very secret and mysterious. They are not apt to have very quick resentments, they have not the same liberty and boldness of language which characterize Europeans, and they have fears too themselves which makes it more likely that they will conceal anything committed to them by Europeans" (W, 6:381).

${ }^{15}$ David Musselwhite agrees with this general summary: "[T]he strict application of the rules of evidence was to reduce the trial, at times, to something very close to farce. In the first place not one of the Managers was legally trained, and even the Articles of Charge were loosely, not to say sloppily, drafted. Much of the Managers' case, moreover, rested on evidence that was circumstantial and characterologicalguilt to be established by association, self-incrimination and intention-little of which could be admitted as substantive by the rules of the court" (Musselwhite, "The Trial of Warren Hastings," in Literature, Politics and Theory, ed. Francis Barker [London: Methuen, 1986], 86-87).

${ }^{16}$ James Boaden, Memoirs of Mrs. Siddons, interspersed with anecdotes of authors and actors, 2 vols. (London: Henry Colburn, 1827), 1:273. The comedy received only ten performances: not a disaster, but hardly a roaring success. In the face of parental disapproval and public apathy, Burney may well have chosen to suppress evidence of her authorship-especially given the play's hostility toward the heroine's father.

${ }^{17}$ In fact "party" for Burney almost uniformly means "the other party," the Whigs. Despite her own general adherence to a Tory party line, she considered herself politically independent.

${ }^{18}$ Her attendance at the trial was always dependent on the queen's wishes: the queen both provided tickets for Burney and various escorts, and released Burney from court duties on the days she attended the trial.

${ }^{19}$ In her Diary, Burney confessed herself prejudiced in his favor by the gallantry and party independence evidenced by his care for the former: "Dr. Johnson, in his last visit to Lichfield, was taken ill, and waited to recover strength for travelling back to town in his usual vehicle, a stage-coach; - as soon as this reached the ears of Mr. Windham, he set off for Lichfield in his own carriage, to offer to bring him back to town in it, and at his own time." Burney interprets this act of generosity as a sign of nobility and independence: "For a young man of fashion, such a trait towards an old, however dignified philosopher, must surely be a mark indisputable of an elevated mind and character; and still the more strongly it marked a noble way of thinking, as it was done in favour of a person in open opposition to his own party, and declared prejudices" $(D, 2: 102-3)$.

${ }^{20}$ Ironically, however, farce was a form appropriate to the impeachment, not only because of the vulgarity of these legal proceedings, but also because farces such as Samuel Foote's Nabob or Elizabeth Inchbald's A Mogul Tale had been used to expose colonial abuses. From this perspective, Crutchley's contempt, validated by Burney, rebounded against the cause both spectators wished to support.

${ }^{21}$ I should perhaps note that Burney did not hear Burke's account of the Rangpurian atrocities firsthand. She attended the second day of his opening speech, in which he described a pair of political murders, but not the third and fourth days.

${ }^{22}$ English Review 1 (January 1783): 14. 
${ }^{23}$ Windham was the first to raise the question of conversion: in response to Burney's assertion of her belief in Hastings's innocence, he exclaimed, "[T]hen there will be the more glory in making you a convert!" Burney replied silently and characteristically: "If 'conversion' is the word, thought I, I would rather make than be made" ( $D, 3: 431)$.

${ }^{24}$ So Hamlet in his "madness" had claimed, "I could be bounded in a nutshell and think myself king of infinite space-but that I have bad dreams." Yet as Rosencrantz and Guildenstern defined ambition to be the shadow of a dream and thus the shadow of a shadow, Hamlet concludes: "Then are our beggars bodies, and our monarchs and outstretched heroes the beggars' shadows." William Shakespeare, Hamlet, Folger Shakespeare Library (New York: Washington Square Press, 2003), 2.2.273$74,282-84$.

${ }^{25}$ Shakespeare, The Tragedy of King Lear (New York: Signet, 1998), 1.1.64.

${ }^{26}$ Julia Epstein argues that in Burney's novels as well as her journals, "paradigmatic sequences of violence ... engage a subterranean discourse of suppression and expose normally hidden social pain by moving beyond the limits of physical endurance and hence beyond those of social convention. The sequences themselves become a discourse that defines the outer limits of language through the difficulty and necessity of narrating brutality, whether as social or emotional violation or as physical violence (Epstein, The Iron Pen: Frances Burney and the Politics of Women's Writing [Madison: Univ. of Wisconsin Press, 1989], 90). For Elaine Scarry's account of "what atrocities one's own body, muscle and bone structure can inflict on oneself" in torture, see The Body in Pain: The Making and Unmaking of the World (Oxford: Oxford University Press, 1985), 48.

${ }^{27}$ Burney, A Busy Day; or An Arrival from India, in The Complete Plays of Frances Burney, ed. Peter Sabor (London: Pickering and Chatto, 1995), 295-96.

${ }^{28}$ Burney, A Busy Day, 296. 